Article

\title{
Risk Management Framework for Handling and Storage of Cargo at Major Ports in Malaysia towards Port Sustainability
}

\author{
Zuritah A. Kadir ${ }^{1}{ }^{\circledR}$, Roslina Mohammad ${ }^{1, *}$, Norazli Othman ${ }^{1}$, Astuty Amrin ${ }^{1}$, \\ Mohd Nabil Muhtazaruddin ${ }^{1}\left(\mathbb{D}\right.$, Siti Hawa Abu-Bakar ${ }^{2}$ and Firdaus Muhammad-Sukki ${ }^{3}(\mathbb{C}$ \\ 1 UTM Razak Faculty of Technology and Informatics, Universiti Teknologi Malaysia, Kuala Lumpur 54100, \\ Malaysia; Zuritah@gmail.com (Z.A.K.); norazli.kl@utm.my (N.O.); astuty@utm.my (A.A.); \\ mohdnabil.kl@utm.my (M.N.M.) \\ 2 Renewable Energy Research Laboratory; Electrical Engineering Section, British Malaysian Institute, \\ Universiti Kuala Lumpur, Gombak 53100, Malaysia; hawa012@gmail.com \\ 3 School of Engineering, Robert Gordon University, Aberdeen AB10 7GJ, UK; f.b.muhammad-sukki@rgu.ac.uk \\ * Correspondence: mroslina.kl@utm.my
}

Received: 2 December 2019; Accepted: 7 January 2020; Published: 9 January 2020

\begin{abstract}
Risk management provides an effective method for ensuring safety and preventing accidents towards achieving port sustainability. This article describes a study of the implementation of a risk management framework for handling of cargo at ports. To achieve the study's objectives, data was collected using a questionnaire and disseminated to port experts at three major ports in Malaysia. The collected data were analyzed using the Statistical Package for the Social Sciences (SPSS) software and calculated using risk matrix calculations. Based on the calculations, for port A and port B, $42 \%$ of risk falls under risk category II and 58\% under risk category III. Meanwhile, for Port C, 31\% under risk category II and $69 \%$ under risk category III. Risk reduction measures should be implemented within a defined period of time (12 months). Additional risk control measures were proposed accordingly. The novelty of the study was an improvement of risk management framework. The risk management framework was proposed with an introduction of risk frequency into risk rating calculation, risk criteria parameter for risk likelihood and risk severity, new risk matrix dimension and instruments to evaluate the existing control measure factor and new risk categories with five levels which provide more details and sustainable risk assessment method.
\end{abstract}

Keywords: port sustainability; risk management; safety; accident; transport and logistics

\section{Introduction}

In Malaysia, seaports are an important component of the maritime and trade industry which have led to the tremendous growth of ports and shipping activities. Ports and shipping are recognized as vital economic contributors in facilitating Malaysia's trade via exports, imports and transshipments and is hence crucial to the economic prosperity of the country. Due to this, ports have taken on a central position in industries engaged in international maritime transport, and issues of economic stability and corporate responsibility have acquired great importance in port operations. Ports need to take the necessary steps to ensure that our environment, communities, people and the ports themselves are positioned for continued success for years to come. The sustainable orientation of ports is firmly anchored upon ports' business strategies. In order to develop sustainable ports, it is very crucial for ports to adopt an effective sustainability governing and measurement system. In the past major attention was given towards green and environmental issues, but nowadays the concept of sustainability has expended to not only be concerned with the environment, but also to concerns about 
people and social impact. Under United Nations Sustainability Goal Development Number Nine: "Industry, Innovation and Infrastructure", it has been reported that efficient transportation services are key drivers of economic development, and more than $80 \%$ of world merchandise trade by volume is transported by sea, making maritime transport a critical enabler of trade and globalization. It was reported that international maritime freight increased globally by an estimated 3.7\% in 2017 and the projected growth will test the capacity of the existing maritime transport infrastructure to support increased freight volumes.

There has been limited attention on sustainability issues in the field of shipping, port and maritime logistics, commonly known as the maritime transport and logistics industry, which have historically received less stakeholder attention as compared to the aviation and overland freight sectors. However, the establishment of International Maritime Organization (IMO) regulations on ships and ports and cities has drawn and increased the attention of stakeholders in the industry to sustainability issues across all the sectors, such as, aviation, land transport, and supply chains [1].

\section{Literature Review}

Safety and security in ports has been said to be one of the great achievement milestones in port sustainability. According to Kang and Kim [2], some international agencies such as the International Maritime Organization (IMO) and ports around the world have undertaken initiatives addressing safety and security issues in the management of port sustainability. One of the main issues raised is accident prevention, as once an accident has happened, it will not only impact environmental issues such as oil spillage, but it will eventually impact the people and economics of the port itself. Thus, in this study, we would like to propose an improvement of the current risk management framework and integrate it with the main sustainability impact features which are the environment, economics and people.

Sislian et al. [3] has highlighted that the most common sustainable development measures focus on environmental measures and that future research could be to incorporate triple bottom line sustainable indicators in the network design linear programming model. It is no longer a question of port or environment or society, but port and environment and society aligned with logistics network optimization. The authors suggested that future research could integrate some other indicators in the sustainability concept such as safety, operational or trade criteria.

The massive development of the shipping industry has not been at the same pace as the development of port sustainability in safety management systems [4]. Major accidents at ports are still a common occurrence. Complex and varied activities are performed in port terminals such as passenger transport, cargo transport, oil and chemicals storage, vehicle storage and transport, ship, lorry and train circulation, etc. which all create more risks and hazards. Incidents such as traffic accidents, oil spills, ship collisions, explosions and injuries [5] are among the accidents that occur in ports. Multiple complex activities create many risk exposures which then lead to accidents. Unmanageable risks result in unwanted events such as accidents and near misses to occur.

The Hong Kong Marine Department [6] and the United Kingdom Health and Safety Executive [7] rank cargo handling activities as one of the highest potential accident risks in port operations. This scenario also aligns with conditions at major ports in Malaysia. Port Klang, one of the largest and busiest ports in Malaysia, recorded a total of 445 accidents in 2017. From those 445 accidents, $88 \%$ (376 cases) happened during cargo handling operations, $1 \%$ (five cases) were marine accident cases and $10 \%$ (44 cases) were miscellaneous cases such as accidents at administration buildings and during maintenance activities. Many accidents happen during the handling and storage of the cargo in ports, especially if the activity involves manual handling as the employees are directly exposed to hazards and risks [8]. The complexity and variety of activities performed in port terminals creates more risks and hazards. These risks and hazards affect people, including crews, passengers, port users and port workers, the environment and property such as ships and port facilities [4]. If not managed and controlled, this will create unsafe acts and conditions [5] and may eventually lead to major accidents, 
including fatalities. These activities each have risks that need to be assessed and evaluated to place appropriate control measures to prevent accidents.

Previous studies have developed and highlighted different risk assessment models by utilizing many risk assessment techniques to solve specific problems pertaining to the risk of handling cargo at terminal operations [5,9-15]. However, no common risk assessment framework can be implemented for all types of risks. This study will introduce some common frameworks for identifying all types of risks in port operations and activities. There are six main pieces of legislation that relate to risk management frameworks in ports, as listed below. These six main sets of legislations all emphasize risk management implementation:

(1) Safety of Life at Sea 1974: International Ship and Port Facility Security Code (ISPS Code) [16]

(2) Merchant Shipping Ordinance [17]

(3) International Maritime Organization [18]

(4) Malaysia Port by Law [19]

(5) Occupational Safety and Health Act, 1994 (OSHA) [20]

(6) Factory Machinery Act, 1967 (FMA) [21]

Based on the above, there are two further regulations that establish risk assessment guidelines to complement the legislation. Both regulations have the same objectives in providing a structured and systematic risk assessment methodology to be implemented by the industry:

(1) International Maritime Organization-Formal Safety Assessment, 2002 (FSA) [22]

(2) Occupational Safety and Health Act 1994 (OSHA)-Hazard Identification, Risk Assessment and Risk Control (HIRARC), 2008 [23]

Formal Safety Assessment (FSA) was established by the International Maritime Organization (IMO) in 2002. The main purpose of the guidelines was to enhance maritime safety, including protection of life, health, the marine environment and property, by using risk analysis and cost benefit assessment. Additionally, it suggests methods to develop new regulations for maritime safety, protection of the marine environment by comparing the current and any enhanced or new regulations to find balance between technical and operational issues such as human factor, maritime safety environmental preservation and cost.

FSA guidelines are available for the port, maritime and shipping industry [11]. A literature review shows numerous maritime related risks studies using FSA [24,25]. It also acts as a decision-making tool. It helps organisations handle any decision-making process in implementing any new regulations enforced in terms of operations and cost. Wang et al. [26] explored the FSA for container ships by using fault tree analysis (FTA) for hazard identification and risk evaluation. It was proven that the techniques were efficient and easy to be implemented. As shown in Table 1, formal safety assessment guidelines entail a systematic risk assessment process [27,28], which starts with hazard identification, risk analysis, risk control options, cost-benefit assessment and recommendation for decision making. Many elements of the FSA are implemented in other industries with the main users being the maritime and shipping industry.

Recently, there has been tremendous efforts in adapting FSA for ports and terminals. Pallis [11] proposed Port Risk Assessment (PRA), a risk assessment methodology with reference to the FSA. The main purpose of the research was to implement formal safety assessment frameworks at ports. The proposed methodology examined accidents related to human and environmental risk factors by interviewing port experts to determine the risk control options. All the proposed risk control options involved cost but at the same time able to reduce risks.

In Malaysia, there is no specific risk assessment guidelines and frameworks for the port industry. The only applicable risk assessment guidelines available are the Hazard Identification, Risk Assessment, and Risk Control (HIRARC) Guidelines, 2008 [21] which provides general guidelines for any industry in implementing risk assessment systems. Even though the guideline is considered sufficient, as a 
proactive measure, it is essential for specific risk assessment frameworks and guidelines for ports to be established as a step towards preventing accidents and managing safety at ports.

Table 1. Details of Formal Safety Assessment Steps [11].

\begin{tabular}{cccc}
\hline Step & Step Details & Step Purpose & Step Techniques \\
\hline $\mathbf{1}$ & Hazard identification & Identify all critical hazards & $\begin{array}{c}\text { Brainstorming, accident analysis, } \\
\text { Interview, task analysis }\end{array}$ \\
\hline $\mathbf{2}$ & Risk analysis & $\begin{array}{c}\text { Detailed investigation of the } \\
\text { identified risk in step 1. }\end{array}$ & $\begin{array}{c}\text { Qualitative or quantitative risk } \\
\text { analysis }\end{array}$ \\
\hline $\mathbf{3}$ & Risk control options & $\begin{array}{c}\text { Propose effective and practical } \\
\text { Risk control options }\end{array}$ & Structured review techniques \\
\hline $\mathbf{5}$ & Cost-Benefits assessment & $\begin{array}{c}\text { Determining the cost efficiency } \\
\text { by Cost/benefit assessment of } \\
\text { port risk control measures }\end{array}$ & Cost benefit analysis \\
\hline & Decision Making & $\begin{array}{c}\text { Define recommendations or } \\
\text { action plan for improvement. }\end{array}$ & Reports, proposal \\
\hline
\end{tabular}

The main purpose of the 2008 Hazard Identification, Risk Assessment, and Risk Control (HIRARC) guidelines, is to provide a systematic and structure risk assessment methodology which can be applied and implemented by all organisations in Malaysia in effort to manage their employee's safety and health at work. This is also a proactive action in managing safety and health concerns in Malaysia. The outcome of this methodology enables employers to introduce control measures and monitor the adequacy of these control measures from time to time. The core of this guideline is to implement control measures to manage risk. If the risk is found to be significant or high, efforts must be made to lower or minimize the risk.

In terms of application, both legislations were established with the same objective in providing structured and systematic risk assessment methodologies for implementation. A comparison between the FSA and HIRARC is provided in Table 2 below. As tabulated, both legislations are focused on compliance and control in line with existing international and national laws and regulations. The FSA was designed specifically for maritime safety risk whilst the HIRARC is general in its scope and applicable to all industries in Malaysia. Based on Table 2, risk identification, risk analysis, risk evaluation and risk control are the main components of risk management and reflected in most legislation.

Table 2. Comparison between Formal Safety Assessment and Hazard Identification, Risk Assessment and Risk Control.

\begin{tabular}{|c|c|c|}
\hline & Formal Safety Assessment, 2002 & $\begin{array}{c}\text { Hazard Identification, Risk } \\
\text { Assessment and Risk Control } \\
\text { (HIRARC), } 2008\end{array}$ \\
\hline Main Objectives & Compliance and Control & Compliance and Control \\
\hline Scope & Focused on maritime safety risk. & $\begin{array}{l}\text { General and applicable to all } \\
\text { industries in Malaysia. }\end{array}$ \\
\hline Main components/steps & $\begin{array}{l}\text { 1. Hazard identification } \\
\text { 2. Risk analysis } \\
\text { 3. Risk control options } \\
\text { 4. Cost-benefits assessment } \\
\text { 5. Recommendations for } \\
\text { decision-making }\end{array}$ & $\begin{array}{l}\text { 1. Classify work activities } \\
\text { 2. Hazard identification } \\
\text { 3. Analyse and estimate risk } \\
\text { 4. Selecting control } \\
\text { 5. Implement } \\
\text { 6. Review and monitoring }\end{array}$ \\
\hline
\end{tabular}

In terms of risk assessment frameworks, the comparison is as per Tables 3 and 4 . Differences were found in the risk assessment process as FSA used expert review and brainstorming and did not specify the process of risk identification. Meanwhile, HIRARC employed risk identification methodology for 
three categories of hazard (Health, Safety, Environment) which give additional value to the standards. Other significant differences were also found in FSA. Its dimension of consequence is elaborated similar to PHSEMS which carries an identical implication for the decision-making process. Both FSA and HIRARC are using qualitative risk matrix assessment.

Table 3. Comparison of Legislation based on main components.

\begin{tabular}{ccccccc}
\hline Legislation & $\begin{array}{c}\text { Establishing } \\
\text { the Context }\end{array}$ & $\begin{array}{c}\text { Hazard } \\
\text { Identification }\end{array}$ & $\begin{array}{c}\text { Risk } \\
\text { Analysis }\end{array}$ & $\begin{array}{c}\text { Risk } \\
\text { Evaluation }\end{array}$ & $\begin{array}{c}\text { Risk } \\
\text { Control }\end{array}$ & $\begin{array}{c}\text { Additional } \\
\text { Features }\end{array}$ \\
\hline $\begin{array}{c}\text { Formal Safety } \\
\text { Assessment (FSA), }\end{array}$ & - & Yes & Yes & Yes & Yes & $\begin{array}{c}\text { Cost-benefits } \\
\text { assessment } \\
\text { Recommendations } \\
\text { for decision-making }\end{array}$ \\
\hline $\begin{array}{c}\text { Hazard } \\
\text { Identification, Risk } \\
\text { Assessment and Risk } \\
\text { Control (2008) }\end{array}$ & Yes & Yes & Yes & Yes & Yes & $\begin{array}{c}\text { Classify work } \\
\text { activities } \\
\text { Monitoring and } \\
\text { Review }\end{array}$ \\
\hline
\end{tabular}

Table 4. Risk assessment processes for each Legislations.

\begin{tabular}{|c|c|c|c|c|}
\hline Legislations & $\begin{array}{c}\text { Identification of } \\
\text { Risk }\end{array}$ & $\begin{array}{l}\text { Risk Assessment } \\
\text { Techniques }\end{array}$ & Risk Evaluation & Risk Control \\
\hline $\begin{array}{c}\text { Formal Safety } \\
\text { Assessment, } 2002\end{array}$ & $\begin{array}{l}\text { Expert review and } \\
\text { brainstorming }\end{array}$ & $\begin{array}{c}\text { Qualitative-Risk matrix } \\
\text { (Risk = Likelihood X } \\
\text { Severity) } \\
\text { The consequence } \\
\text { expressed details into } \\
\text { People, Asset, } \\
\text { Environment and Image. } \\
\text { Likelihood also more } \\
\text { details }\end{array}$ & $\begin{array}{l}\text { Based risk rating. } \\
\text { Risk level (High, } \\
\text { Low, Medium) }\end{array}$ & $\begin{array}{l}\text { Developed risk } \\
\text { control option }\end{array}$ \\
\hline $\begin{array}{c}\text { Hazard } \\
\text { Identification, } \\
\text { Risk Assessment } \\
\text { and Risk Control } \\
\text { (HIRARC), } 2008\end{array}$ & $\begin{array}{l}\text { Three categories of } \\
\text { hazard (Health, } \\
\text { Safety, } \\
\text { Environment). } \\
\text { Provide risk } \\
\text { identification } \\
\text { methodology. }\end{array}$ & $\begin{array}{c}\text { Qualitative/Semi } \\
\text { quantitative-Risk matrix } \\
\text { (Risk = Likelihood X } \\
\text { Severity) } \\
\text { Simple likelihood and } \\
\text { Severity margin }\end{array}$ & $\begin{array}{l}\text { Based risk rating. } \\
\text { Risk level (High, } \\
\text { Low, Medium) }\end{array}$ & $\begin{array}{l}\text { Hierarchy of } \\
\text { control }\end{array}$ \\
\hline
\end{tabular}

The Malaysian HIRARC guideline as shown in Figure 1 provides a guideline for simple operation activities. The existing HIRARC framework using a risk assessment table or risk matrix has been widely used in many studies in other applications such as hotel services, hydroelectric power generation plants, schools or education, crane operations, road accidents and manufacturing. The main steps of the HIRARC method are mainly used by risk management research. The HIRARC process is based on the four steps: (1) risk classification, (2) risk identification, (3) risk analysis and estimation and (4) risk control. The guideline has a framework that uses a qualitative risk matrix assessment, a simple calculation of risk rating and categorizes risks into three levels, not considering the existing control measure. These limitations lead to a challenging implementation of risk management in the Malaysian port industry. The existing risk management framework used only qualitative risk matrix assessment. Thus, this study proposes a risk assessment framework with a new risk calculation. A new risk calculation method with new improved risk parameter variables was also introduced. In addition, there is a gap in evaluating the existing control measure in the existing risk management. This study introduces an instrument to evaluate the existing control measure factor to the risk value calculation at risk evaluation stage. The main issues are found in classic risk matrix analysis as it is typically structured based on one dimension of consequence and one dimension of probability. 


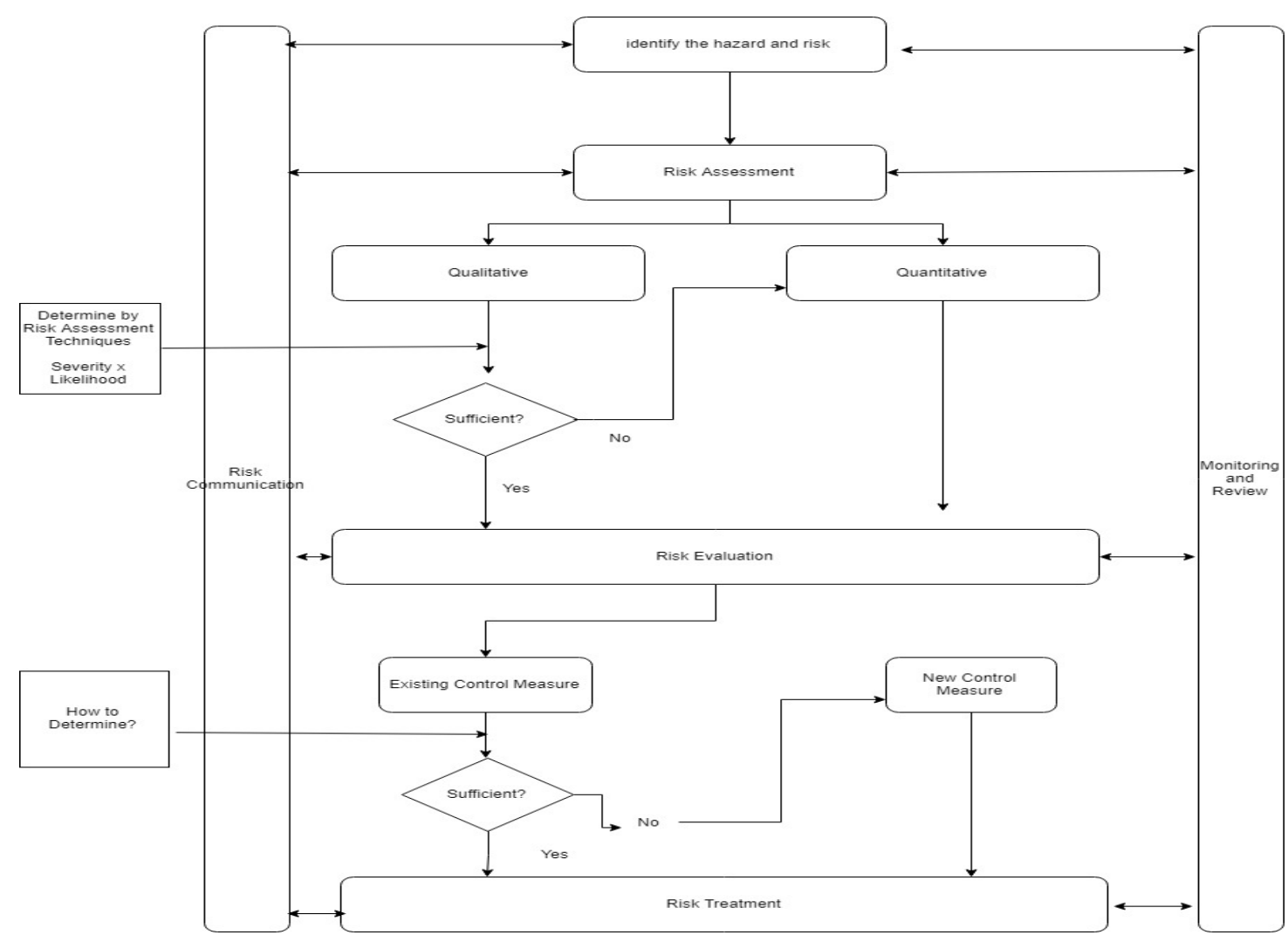

Figure 1. Gap in current risk assessment framework in Hazard Identification, Risk Assessment and Risk Control guidelines.

In reality, most risks produce more than one consequence. This reflects on the definition of risk itself as a combination of the likelihood of an occurrence of a hazardous event within a specified period or under specified circumstances and the severity of injury or damage to the health of people, property, environment or any combination of these caused by the event. Thus, it is not relevant to interpret the consequence of risk from only one consequence. This can increase uncertainty and bias as it affects the analysis into likelihood and severity. This also does not reflect the sustainability which shows the gap between the current risk management frameworks in sustainability aspect.

\section{Methodology}

In this study, to assess the risk factors of handling and storage of cargo at ports, the HIRARC method was applied as the main analysis tool, however improvement of the framework has been made to suit the port suitability. The Malaysian HIRARC 2008 guideline provides a guideline for simple operation activities. The guideline has a framework that uses a qualitative risk matrix assessment, a simple calculation of risk rating and categories risks into three levels, not considering the existing control measures. These limitations lead to a challenging implementation of risk management in the Malaysian port industry. Therefore, this study aims to propose an improvement to the risk management framework for the handling and the storage of cargo at ports in Malaysia to prevent and control accidents and to implement effective safety and health management. An improvement of risk management framework was developed with identification of risk factors in handling and storage of cargo in ports. Besides that, an enhancement was proposed with an introduction of risk frequency into risk rating calculation, risk criteria parameter for risk likelihood and risk severity, new risk matrix dimension and instruments to evaluate the existing control measure factor and new risk categories with five levels as shown in Figure 2. 


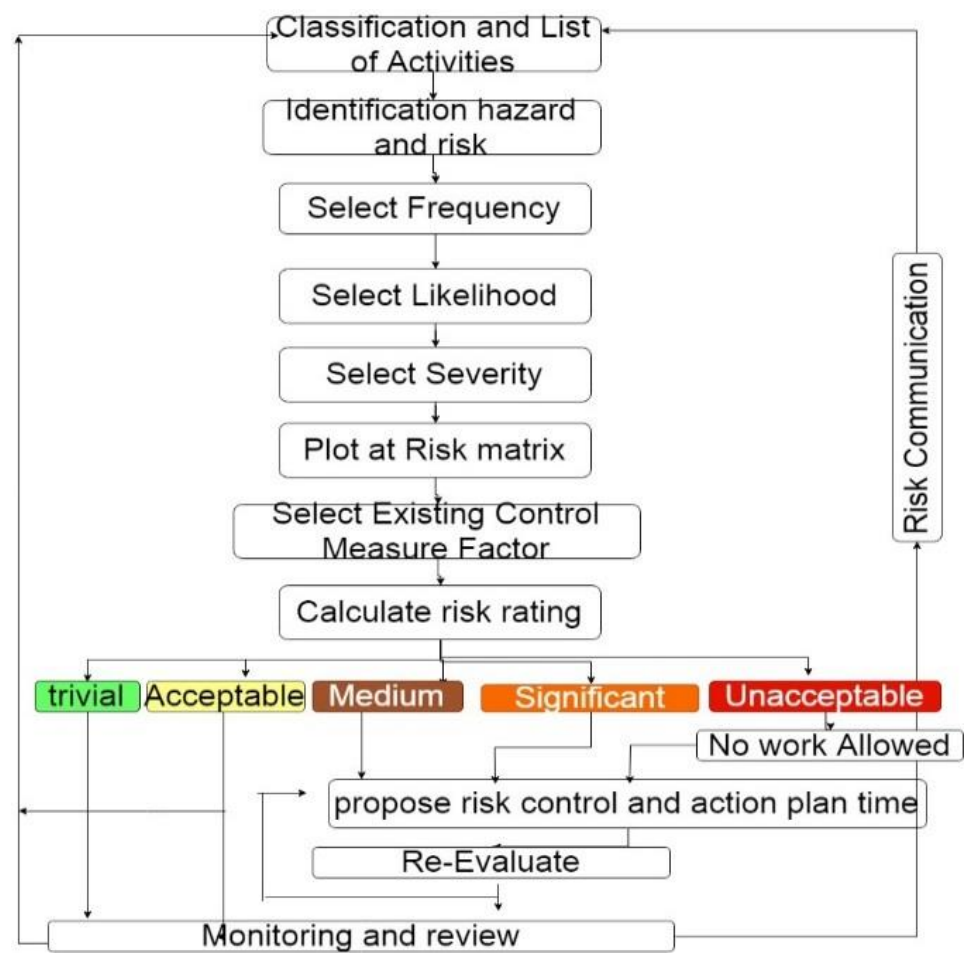

Figure 2. Risk Management Framework with enhancement [29].

\subsection{Classification of Work Activities}

Port experts and port representatives provided a briefing on cargo handling activities at port operations. In this operation, the cargo is handled based on their type. Container operations involve loading and unloading of containers from vessels onto the prime mover or haulage using a quay crane. The conventional operation is divided into two categories which are bulk operation and roll on-roll off (RO-RO) operation. The RO-RO operation involves wheeled cargo, e.g., cars, trucks, construction vehicles that can drive on and off the ship on their own or on special trailers. Bulk operations are divided into three categories which are break bulk, liquid bulk and dry bulk. Liquid bulk involves liquid substances carried in bulk in ships' tanks, including oil, oil derivatives and chemical cargoes such as oil and gas. Several ports in Malaysia solely provide as liquid bulk terminals which handle both non-dangerous goods such as palm-oil and dangerous goods such as liquefied natural gas (LNG) and petroleum. There are also dangerous goods packed in containers as well as tankers and loose cargo which pose risks such being explosive, corrosive or present a fire and/or environmental risk. Dry bulk involves solid substances such as iron ore, coal and grain. It is handled by luffing cranes or winch cranes. Breakbulk or general cargo refers to any loose materials or items that must be loaded individually, such as steel plate or coils, packaged lumber and heavy machinery.

\subsection{Risk Identification}

To identify the critical risk factors of handling cargo activities in ports, a combination of literature reviews and brainstorming with port experts were conducted. The same method was practiced by Mokhtari et al. [30]. Brainstorming with port experts was conducted to ensure that the factors identified by literature but not relevant to actual handling activities at port terminal operations are not considered. A total of 57 risk factors were identified, as listed in Appendix B.

\subsection{Risk Analysis and Estimation}

The following describes the risk assessment criteria in this study. The risk assessment criteria were validated by port experts. The likelihood of occurrence was defined by a scale from 1 (very unlikely) 
to 5 (certain) as per Table 5. The likelihood is assessed without considering the presence of control measures. In order to reduce uncertainty and bias, the parameter of risk likelihood was explained based on percentage bases and number of occurrences.

Table 5. Likelihood of occurrence (L). Adapted from Formal Safety Assessment with Enhancement [29].

\begin{tabular}{cccc}
\hline & $\begin{array}{c}\text { Likelihood of } \\
\text { Occurrence (L) }\end{array}$ & Percentage Basis & Number of Occurrences \\
\hline 1 & Very unlikely & $\begin{array}{c}\text { The probability to happen is } \\
\text { extremely small }(<1 \%)\end{array}$ & No cases known \\
\hline 2 & Unlikely & $\begin{array}{c}\text { Could happen, however very rare } \\
(1 \text { to } 9 \%)\end{array}$ & One case within 5 to 10 years \\
\hline 3 & Likely & Chances to happen is relatively \\
high $(10$ to $59 \%)$ & One case within 1 to 5 years \\
\hline 5 & Most likely & Can happen frequently (60 to $94 \%)$ & One case within 6 months to \\
& Certain & Expected to happen $(95$ to $100 \%)$ & Once case in less than 6 months \\
\hline
\end{tabular}

The severity of the occurrence was defined by a scale of 1 to 5 as described in Table 6 . In order to reduce bias and uncertainty, an explanation of variables is provided. In order to integrate the aspect of sustainability, the consequence was made based on judgement on the impact to people, asset, environment and reputation of the organization.

Table 6. Severity of Harm (S). Adapted from Formal Safety Assessment with Enhancement [29].

\begin{tabular}{cc}
\hline Level & Risk Level \\
\hline 1 & Negligible \\
2 & Minor \\
3 & Major \\
4 & Critical \\
5 & Catastrophe \\
\hline
\end{tabular}

Note: Details of List Severity are given in Appendix A.

The frequency is based on the activity conducted. In this study the frequency was calculated and defined based on a scale of 1 to 5 as described in Table 7 .

Table 7. Frequency of Activity (F) [29].

\begin{tabular}{ccc}
\hline Level & Frequency & Description \\
\hline 1 & Yearly & 1 to 10 times in a year \\
2 & Monthly & 1 to 3 times in a month \\
3 & Weekly & 1 to 3 times in a week \\
4 & Daily & 1 to 5 times in a day \\
5 & Hourly & Once or more in an hour, or $>5$ times in a day \\
\hline
\end{tabular}

In order to analyse the risk, the risk likelihood, risk frequency and risk severity was calculated according to the below calculation and the results placed in Table 8 below:

$$
\text { Risk Value }=\mathrm{L} \times \mathrm{S} \times \mathrm{F}
$$

where the variables are Likelihood of Occurrence (L), Severity of Harm (S; the value of S shall be taken as the highest value of People, Asset, Environment, and Image) and Frequency of Activity (F). 
Table 8. Risk Level and Action to be Taken [29].

\begin{tabular}{cccc}
\hline Risk Rating & Risk Category & Risk Level & Action and Time Scale \\
\hline $1-9$ & I & Trivial & No action required \\
\hline $10-26$ & II & Acceptable & $\begin{array}{c}\text { No additional controls required. Monitoring } \\
\text { required in ensuring existing controls } \\
\text { are maintained. }\end{array}$ \\
\hline $48-64$ & III & Moderate & $\begin{array}{c}\text { Efforts may be made to reduce the risk. Risk } \\
\text { reduction measures should be implemented within a } \\
\text { defined period of time (12 months). }\end{array}$ \\
\hline$>=65$ & Significant & $\begin{array}{c}\text { Efforts shall be made to reduce the risk. Risk } \\
\text { reduction measures should be implemented within a } \\
\text { defined period of time (6 months). }\end{array}$ \\
\hline V & Unacceptable & $\begin{array}{c}\text { Work should not be started until the risk has been } \\
\text { reduced. Considerable resources shall be allocated to } \\
\text { reduce the risk. If the risk hinders work in progress, } \\
\text { urgent action (within 7 working days, min, and } \\
\text { admin control) shall be taken. }\end{array}$ \\
\hline
\end{tabular}

\subsection{Risk Control}

Based on the risk calculation, the modified risk matrix was categorized into five categories according to the risk rating. This was made based on the basis of the risk being reduced to As Low as Reasonable Practice (ALARP). The recommended actions and time scale for corrective action plans (new risk control) are detailed in Table 5. Once the risk was evaluated and categorized, the risk control was proposed based on the hierarchy of control. In this study, the risk control is proposed based on the hierarchy of control adapted from the HIRARC guideline.

\subsection{Data Collection}

In order to conduct the risk assessment, the identified risk factors and risk assessment criteria were rendered into the form of a questionnaire. This allowed the data collection process to be simplified and standardized. There were two parts of questionnaires constructed for this study. The identified 57 risk factors by port experts as listed in Table 5 . The risk frequency, risk likelihood, risk severity was converted into a five-level Likert scale.

The questionnaire was distributed to three major ports located in the Malaysia. The three ports are multipurpose ports and the busiest ports in Malaysia which have various operations of port services involving container operations, liquid bulk operations, dry bulk operation, ferry operations, vehicle transit centers, roll on-roll out operation, marine services and dangerous goods storage operations. Port experts including supervisors and higher level management who are involved in terminal operations were invited to complete the questionnaire. To increase the response rate, the questionnaire was completed during interviews conducted by the authors. A total of 191 completed questionnaires were collected out of the 300 questionnaires distributed. The same method was applied by Yang et al. [12] and Shang and Tseng [9].

\section{Results and Discussion}

\subsection{Development of Risk Management Framework}

Pallis [11] has stated that there are no specific standardized risk management frameworks. In Malaysia, there is still uncertainty regarding the availability of standardized frameworks capable of serving all types of systems and risks. Thus, risk management frameworks that followed the HIRARC framework were developed based on a few considerations. The first consideration is based on legal requirements. The HIRARC model follows local regulations and guidelines under Occupational Safety 
and Health Act 1994 (Act 514)—HIRARC 2008 [22]. Second, based on the same theme as the first consideration, since the local guidelines follow the HIRARC model, it would be easier for ports in Malaysia to adapt the model. This will increase understanding of the risk management process and reduce uncertainty and bias. The third consideration is based on the risk assessment techniques in the HIRARC model. The risk matrix is a structured technique, easily explained and understood, making it simple to implement and adopt. The risk calculator and the semi-quantitative risk rating matrix are identified as the most preferred methods for risk analysis. It is an advantage to apply this technique in a complex scenario. The model can help risk managers develop highly efficient risk management strategies across multiple risk levels in accordance with various risk factors, helping lessen loss occurrence rates and thereby reducing corporate financial losses. The risk matrix model is also employed by many risk management frameworks. The fourth consideration is based on data availability. Previous studies have shown that the main focus of risk assessment research is the integration of both methodologies (qualitative and quantitative) to generate solutions. Previous studies also suggested that risk assessment be measured by utilizing historical accident data. The data can be analyzed qualitatively and quantitatively by using various statistical methods. In order to perform this, it requires large historical accident data which are not readily available even from the Department of Occupational Safety and Health, Malaysia online database. Due to limitation of large historical accidents data in Malaysia availability, the research shall be relied on experts' knowledge. Compared to the qualitative and quantitative methods, the semi quantitative risk analysis seems to be more realistic as per the HIRARC theoretical framework discussed earlier.

Even though the frameworks follow the HIRARC model, some enhancement criteria from other standards, legislations and guidelines were introduced in developing the frameworks. Enhancement criteria that have been adapted are as below:

(1) Identification of risk factors in handling and storage of cargo in ports based on literature review and validated by experts.

(2) Risk criteria parameter for risk likelihood and risk severity was adopted from Formal Safety Assessment (FSA) guidelines with modification to fit Malaysia's standards and requirements.

(3) An improvement to the risk management framework was developed with identified risk factors in handling and storage of cargo in ports based on the literature review and validation by experts. The improvement proposed were the introduction of risk frequency into risk rating calculation, improved risk criteria parameter for risk likelihood and risk severity, new risk matrix dimension, an instrument to evaluate of existing control measure factor and five level of risk categories.

\subsection{Risk Analysis and Estimation}

The mean of frequency, likelihood and severity of the risk factors associated with handling and storage of cargo at port terminals tasks in the questionnaires are shown in Appendix C. In order to analyse the risk, the mean value of risk frequency, risk likelihood and risk severity was multiplied to obtain the risk value. The results of the study were categorized into risk level accordingly as tabulated in Table 9. 
Table 9. Risk Analysis and Estimation.

\begin{tabular}{|c|c|c|c|c|}
\hline Risk Category & Port A & Port B & Port C & $\begin{array}{l}\text { Action and Time } \\
\text { Scale }\end{array}$ \\
\hline I (Trivial) & Nil & Nil & Nil & No action required \\
\hline II (Acceptable) & $\begin{array}{l}\text { R8, R11, R12, R13, } \\
\text { R14, R15, R16, R23, } \\
\text { R24, R25, R27, R28, } \\
\text { R32, R34, R36, R42, } \\
\text { R46, R47, R48, R50, } \\
\text { R52, R54, R55, R56 }\end{array}$ & $\begin{array}{c}\text { R8, R10, R11, R12, R13, } \\
\text { R14, R16, R17, R22, } \\
\text { R23, R24, R25, R27, } \\
\text { R28, R29, R30, R31, } \\
\text { R32, R36, R37, R38, } \\
\text { R39, R42, R43, R44, } \\
\text { R46, R47, R49, R50, } \\
\text { R52, R54, R55, R56 }\end{array}$ & $\begin{array}{c}\text { R8, R9, R10, R11, R12, } \\
\text { R13, R14, R15, R16, } \\
\text { R22, R23, R24, R25, } \\
\text { R27, R28, R30, R32, } \\
\text { R36, R37, R38, R39, } \\
\text { R41, R42, R43, R44, } \\
\text { R46, R47, R48, R49, } \\
\text { R50, R52, R53, R54, } \\
\text { R55, R56 }\end{array}$ & $\begin{array}{c}\text { No additional controls } \\
\text { required. Monitoring } \\
\text { required ensuring } \\
\text { existing controls are } \\
\text { maintained. }\end{array}$ \\
\hline III (Moderate) & $\begin{array}{c}\text { R1, R2, R3, R4,R5, } \\
\text { R6, R7, R9, R10, } \\
\text { R17, R18, R19, R20, } \\
\text { R21,R22, R26, R29, } \\
\text { R30, R31, R33, R35, } \\
\text { R37, R38, R39, R40, } \\
\text { R41, R43, R44, R45, } \\
\text { R49, R51, R53, R57 }\end{array}$ & $\begin{array}{c}\text { R1, R2, R3, R4, R5, R6, } \\
\text { R7, R9, R15, R18, R19, } \\
\text { R20, R21, R26, R33, } \\
\text { R34, R35, R40, R41, } \\
\text { R45, R48, R51, R53, R57 }\end{array}$ & $\begin{array}{c}\text { R1, R2, R3, R4, R5, R6, } \\
\text { R7, R17, R18, R19, R20, } \\
\text { R21, R26, R29, R31, } \\
\text { R33, R34, R35, R40, } \\
\text { R45, R51, R57 }\end{array}$ & $\begin{array}{l}\text { Efforts may be made to } \\
\text { reduce the risk. Risk } \\
\text { reduction measures } \\
\text { should be } \\
\text { implemented within a } \\
\text { defined time period (12 } \\
\text { months) }\end{array}$ \\
\hline IV (Significant) & Nil & Nil & Nil & $\begin{array}{l}\text { Efforts shall be made to } \\
\text { reduce the risk. Risk } \\
\text { reduction measures } \\
\text { should be } \\
\text { implemented within a } \\
\text { defined period of time } \\
\text { (6 months). }\end{array}$ \\
\hline V(Unacceptable) & Nil & Nil & Nil & $\begin{array}{l}\text { Work should not be } \\
\text { started until the risk } \\
\text { has been reduced. } \\
\text { Considerable resources } \\
\text { shall be allocated to } \\
\text { reduce the risk. If the } \\
\text { risk hinders work in } \\
\text { progress, urgent action } \\
\text { (within } 7 \text { working } \\
\text { days, min, and admin } \\
\text { control) shall be taken. }\end{array}$ \\
\hline
\end{tabular}

(1) No risk factor falls under risk category I, risk level 'trivial'. For category I, risk category IV (Significant) and category V (Unacceptable) for all ports, no action is required as the risk is under control and manageable.

(2) The highest risk for Port A and Port B was Communication misunderstanding (R2). Meanwhile for Port $\mathrm{C}$, the highest risk rating was fatigue (R51). Findings for R2 (Communication misunderstanding) as the highest risk were similar to the findings by Ding and Tseng [31]. Yang et al. [12] found that worker's individual experience as a significant risk. However, in this study, it came under acceptable risk. Sunaryo and Hamka [32] also highlighted human error as a root cause of accidents. Azmi [33] found that health risks, especially ergonomics issues, were a concern among port operators. The study argued that the prevalence of low back pain is significant among Malaysian port workers. Gravity risk factor relates to falls, slip and trip and suspended loaded risk in the port industry. The risk was found to be most significant by Alyami et al. [13], Alyami et al. [14] and Sunaryo and Hamka [32].

(3) As showed in Figure 3, for port A and port B, $42 \%$ of risk falls under risk category II and 58\% under risk category III. Meanwhile, for Port C, 31\% under risk category II and 69\% under risk category III. 


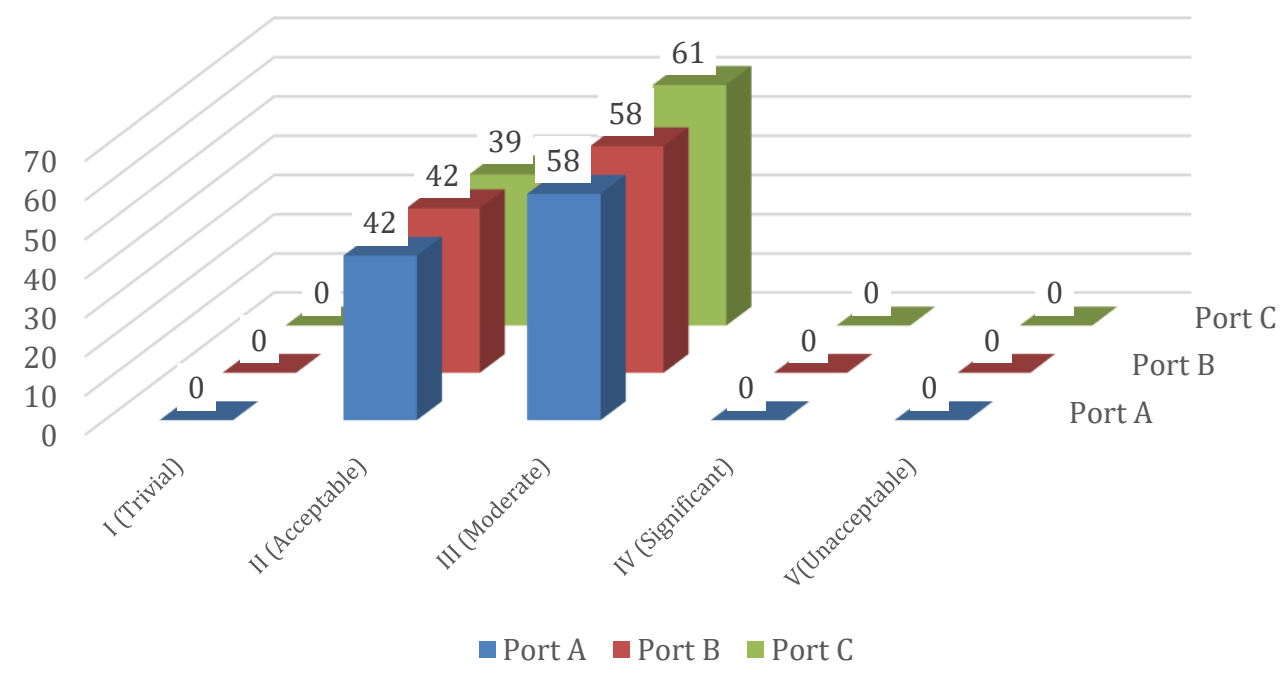

Figure 3. Risk Categories for Each Port.

(4) Comparison between three ports, Port $C$ can be said as the most risk port compared to Port $A$ and $\mathrm{B}$ as Port $\mathrm{C}$ has highest number of risks under category III as showed in Figure 3.

As the main purpose of risk management is to ensure the risk raised from work activities are controllable and reduced to ALARP, risks that fall under risk category III are required to be subjected to additional control measures to ensure that the risk falls under risk categories I or II.

\subsection{Risk Impact}

Under United Nation Sustainability Goal Development Number Nine: “Industry, Innovation and Infrastructure", it has been reported many workers around the world are exposed to undue risks in their workplaces. Based on recent data from some 55 countries, a median of three deaths occurred per 100,000 employees and a median of 889 non-fatal injuries occurred per 100,000 employees.

In this study, sustainability features for risk impact or risk severity are proposed. Based on the analysis, it can be found that most of risks fall under level severity minor and major, as shown in Appendix C. This indicates that if any accident of minor severity happens due to that risk, it will impact minor injuries or health effects including first aid cases and outpatient medical treatment or, affecting work performance due to restriction of activities, or require a few days to recover or, affect only personnel involved in the activity. For environment impact, minor damage is when the repair cost is greater than RM 10,000 but less than RM 100,000. Contamination and damage are sufficient to attack the environment at a site. For reputation, it will cause some local public concern.

Meanwhile, if the severity of the risk is major, it may involve major injuries or health effects, affecting work performance for a longer term such as prolonged absence from work, hospitalization, or a disabling injury, but is recoverable or affects only personnel in the local department. For the environment, limited loss due to discharges of known toxicity may cause sufficient damage to attack the environment within the port area, resulting in significant damage with repair costs greater than RM 100,000 but less than RM 500,000. It has potential to exceed environmentally-related statutory requirements, i.e., the environmental quality act. Regional public concern will then grow and attract considerable local media and political attention. As for business or economic impact, it has potential for single violations of business-related regulations or statutory requirements, i.e., business licenses.

\subsection{Risk Control}

Table 9 below lists the risk controls proposed to reduce the risks which fall under Category III. This list is not exhaustive, and the port's management shall be responsible for implementing any management programs required to control and reduce the risks. 


\section{Conclusions}

The main contribution of this research is the development of risk management frameworks for the handling and storage of cargo with enhanced risk assessment methods to improve the risk management framework. The risk management framework was proposed with an introduction of risk frequency into risk rating calculations, risk criteria parameters for risk likelihood and risk severity, new risk matrix dimensions and instruments to evaluate the existing control measure factors and new risk categories with five levels which provide more details and a sustainable risk assessment method. This facilitates the application of risk management to solve occupational safety and health concerns in the area of port sustainability. The developed risk management framework with enhanced risk assessment techniques may solve the problem of integration of sustainability aspects in port safety and risk management. This study has proposed the integration of sustainability aspects in the proposed risk management frameworks by introducing the sustainability features in the "severity" phase where the consequence or impact of accident is not only focused on people but extended to the environment, assets and reputation which cover all aspects of economic sustainability.

Further implementation was carried out in major ports in Malaysia. In this study, the risk for handling cargo at a multipurpose port was analyzed using the HIRARC method. The risks were identified by a combination of an intensive literature review and brainstorming with port experts. The risks identified were analyzed using risk matrix techniques where the risk likelihood, risk severity and risk frequency were determined. A questionnaire form was used to simplify and standardize the data collection process and was distributed at a multipurpose port in Malaysia. Based on the results, additional risk controls were proposed for the risks that fall under category III based on the hierarchy of control implemented by the HIRARC 2008 guidelines. The findings may be summarized as follows:

(1) No risk factor falls under risk category I, risk level 'trivial'. For category I, risk category IV (Significant) and category V (Unacceptable) for all ports, no action is required as the risk is under control and manageable.

(2) The highest risk for Port A and Port B was communication misunderstanding (R2), while for Port $C$, the highest risk rating was fatigue (R51).

(3) As shown in Figure 3, for port A and port B, $42 \%$ of risks fall under risk category II and 58\% under risk category III. Meanwhile, for Port C, 31\% are under risk category II and 69\% under risk category III.

(4) Comparing the three ports, Port C can be said to be most at risk compared to Port A and B as Port $\mathrm{C}$ has highest number of risks under category III.

The outcome of the research is crucial as a supplement to the current knowledge about risk assessment of such systems, risk assessment models and general guidelines for the improvement of current frameworks and procedures. Concurrently, this study shall benefit the participating ports in analyzing their risk management systems. With the results of this research, the port management can implement countermeasures to increase worker safety awareness and safety culture in the port. Authorities such as the Department of Occupational Safety and Health (DOSH), port authorities and marine department will also benefit from this research for guideline formulation purposes. The research investigated the risks of accidents for handling cargo at a multipurpose port in Malaysia. Further research could expand the scope of the study to another four major ports in Malaysia and covered the whole port operations. As an example, research should be extended to financial risk by conducting cost benefit analyses to determine suitable risk strategies and mitigation options. This may improve risk management processes and decision making. In this study, the applicability and flexibility of developed frameworks were implemented in occupational safety and health risk, for the future they should also cover other types of risk such as environment risk, disaster risk and operational risk. 


\section{Patents}

This work has been patented under The Official Portal of Intellectual Property Corporation of Malaysia, Patent Reference: LY2019005313 with title “Risk Management Framework for Handling and Storage of Cargo at Major Port in Malaysia".

Author Contributions: Conceptualization, Z.A.K. and R.M.; Data curation, Z.A.K.; Formal analysis, Z.A.K.; Funding acquisition, R.M., N.O., A.A., S.H.A.-B. and F.M.-S.; Investigation, Z.A.K.; Methodology, R.M.; Project administration, R.M.; Resources, R.M.; Supervision, R.M., N.O. and A.A.; Validation, R.M., N.O. and A.A.; Visualization, Z.A.K., S.H.A.-B. and F.M.-S.; Writing-original draft, Z.A.K.; Writing-review \& editing, Z.A.K., R.M., N.O., A.A., M.N.M., S.H.A.-B. and F.M.-S. All authors have read and agreed to the published version of the manuscript.

Funding: The authors wish to express the utmost appreciation and gratitude to the Ministry of Higher Education, MyBrain15 MyPhD Ministry of Higher Education, UTM Razak Faculty of Technology and Informatics, and Universiti Teknologi Malaysia (UTM) for all the support given in making the study a success. UTM VOTE No: Q.K130000.2540.19H15 and UTM VOTE No: Q.K130000.2656.16J42.

Conflicts of Interest: The author(s) declared no potential conflicts of interest with respect to the research, authorship, and/or publication of this article. The funders had no role in the design of the study; in the collection, analyses, or interpretation of data; in the writing of the manuscript, or in the decision to publish the results.

\section{Appendix A}


Table A1. Severity of Harm (Adapted from the Formal Safety Assessment with Enhancement).

\begin{tabular}{|c|c|c|c|c|c|}
\hline \multicolumn{6}{|c|}{ Severity of Harm (s) } \\
\hline Level & Risk Level & People (P) & Asset (A) & Environment (E) & Reputation (R) \\
\hline 1 & Negligible & $\begin{array}{l}\text { No or slight injury or health effect } \\
\text { including first aid and medical } \\
\text { treatment or, not affecting work } \\
\text { performance or, affecting only } \\
\text { personnel in the activity }\end{array}$ & $\begin{array}{l}\text { Tolerable damage }< \\
\text { RM10,000 }\end{array}$ & $\begin{array}{l}\text { No environmental damage or local } \\
\text { environmental damage within a confined } \\
\text { area }\end{array}$ & $\begin{array}{l}\text { No or slight public awareness may } \\
\text { exist, and there is no public concern. }\end{array}$ \\
\hline 2 & Minor & $\begin{array}{l}\text { Minor injury or health effect } \\
\text { including first aid cases \& outpatient } \\
\text { medical treatment or, affecting work } \\
\text { performance such as restriction to } \\
\text { activities, or requiring a few days to } \\
\text { recover or, affecting only personnel } \\
\text { involved in the activity }\end{array}$ & $\begin{array}{l}\text { Damage with repair costs } \\
>\text { RM10,000, } \\
<\text { RM100,000 }\end{array}$ & $\begin{array}{l}\text { Contamination. Damage sufficient to } \\
\text { attack the environment at the site. }\end{array}$ & Some local public concern. \\
\hline 3 & Major & $\begin{array}{l}\text { Major injury or health effect, or } \\
\text { affecting work performance for a } \\
\text { longer term such as prolonged } \\
\text { absence from work, hospitalization } \\
\text { or disabling injury but recoverable or } \\
\text { affecting only personnel in a local } \\
\text { department }\end{array}$ & $\begin{array}{l}\text { Significant damage with } \\
\text { repair costs }>\text { RM100,000, } \\
<\text { RM500,000 }\end{array}$ & $\begin{array}{l}\text { Limited loss or discharges of known } \\
\text { toxicity. } \\
\text { Damage sufficient to attack the } \\
\text { environment within the port limit area. } \\
\text { Potential for or single infraction of } \\
\text { environmentally- related statutory } \\
\text { requirements, i.e., EQA. }\end{array}$ & $\begin{array}{l}\text { Regional public concern. } \\
\text { Considerable local media and } \\
\text { political attention. } \\
\text { Potential for or single violation of } \\
\text { business-related regulations or } \\
\text { statutory requirements, i.e., business } \\
\text { license. }\end{array}$ \\
\hline 4 & Critical & $\begin{array}{l}\text { Single fatality or permanent total } \\
\text { disability from an incident or } \\
\text { occupational illness (i.e., poison), or } \\
\text { affecting personnel in the factory }\end{array}$ & $\begin{array}{l}\text { Heavy damage with } \\
\text { repair costs > RM500,000, } \\
<\text { RM1,000,000 }\end{array}$ & $\begin{array}{l}\text { Severe environmental damage. } \\
\text { Damage sufficient to attack the } \\
\text { environment at a national level. } \\
\text { Repeated infractions of environmentally- } \\
\text { related statutes or prescribed limits. }\end{array}$ & $\begin{array}{l}\text { National public concern. } \\
\text { Adverse attention in national media. } \\
\text { More than a single violation of } \\
\text { business- related regulations or } \\
\text { statutory requirements, i.e., business } \\
\text { license }\end{array}$ \\
\hline 5 & Catastrophe & $\begin{array}{l}\text { Multiple fatalities from accidents or } \\
\text { occupational illness, or affecting } \\
\text { personnel within and outside the } \\
\text { factory }\end{array}$ & $\begin{array}{l}\text { Damage costs > } \\
\text { RM1,000,000 }\end{array}$ & $\begin{array}{l}\text { Persistent severe environmental damage or } \\
\text { severe nuisance extending over a large } \\
\text { area affecting the international community. } \\
\text { Constant high exceedance of } \\
\text { environmentally- related statutes or } \\
\text { prescribed limits. }\end{array}$ & $\begin{array}{l}\text { International public attention. } \\
\text { Extensive public attention in the } \\
\text { national/ } \\
\text { international media. } \\
\text { Potentially severe impact on access or } \\
\text { renewal of licenses. }\end{array}$ \\
\hline
\end{tabular}




\section{Appendix B}

Table A2. Identified Risks.

\begin{tabular}{|c|c|c|}
\hline Risk Factor Group & Risk No & Risk Descriptions \\
\hline \multirow{8}{*}{ Man } & R1 & Operators' mistakes and faults on operations \\
\hline & $\mathrm{R} 2$ & Communication misunderstanding \\
\hline & R3 & Human carelessness and omissions \\
\hline & R4 & Execution of the job safety rules and regulations \\
\hline & R5 & Worker's Individual workload and stress \\
\hline & R6 & Worker's Individual discipline \\
\hline & R7 & Do not following with normalized operating procedure \\
\hline & R8 & Worker's Individual experience \\
\hline \multirow{16}{*}{ Machines } & R9 & Automation of operations \\
\hline & R10 & Machine/equipment conditions \\
\hline & $\mathrm{R} 11$ & A series of routine and un routine maintenance \\
\hline & $\mathrm{R} 12$ & Secure system \\
\hline & $\mathrm{R} 13$ & Failure of lifting equipment \\
\hline & $\mathrm{R} 14$ & Not selecting inherently safety protection of machines and equipment \\
\hline & $\mathrm{R} 15$ & Requisite safety facilities and equipment tallied with standards \\
\hline & R16 & Personnel safety equipment conditions \\
\hline & $\mathrm{R} 17$ & Field safety equipment conditions \\
\hline & $\mathrm{R} 18$ & Safety-related work environment setup \\
\hline & R19 & Navigation aids \\
\hline & $\mathrm{R} 20$ & Pressure \\
\hline & $\mathrm{R} 21$ & Vehicles \\
\hline & $\mathrm{R} 22$ & Mobile and Fixed Plant \\
\hline & $\mathrm{R} 23$ & Powered Equipment \\
\hline & $\mathrm{R} 24$ & Non-Powered Equipment \\
\hline \multirow{15}{*}{ Management } & $\mathrm{R} 25$ & Communication between work groups \\
\hline & $\mathrm{R} 26$ & Delegation of work \\
\hline & $\mathrm{R} 27$ & Fairness regarding salary and rewards/punishments \\
\hline & $\mathrm{R} 28$ & Carrying out the SOPs \\
\hline & $\mathrm{R} 29$ & On-the-job training and orientation education \\
\hline & $\mathrm{R} 30$ & Not performing a safety auditing and safety inspection \\
\hline & $\mathrm{R} 31$ & Operation safety protocols \\
\hline & $\mathrm{R} 32$ & Implementation of safety education (awareness) \\
\hline & R33 & Training and assessment of operation skills \\
\hline & $\mathrm{R} 34$ & Top manager support to strengthen the safety climate \\
\hline & R35 & Top manager support to provide sufficient cost for safety programs \\
\hline & R36 & Individual understanding of safety protocols \\
\hline & $\mathrm{R} 37$ & Establishment of a culture that values safety \\
\hline & R38 & Poor legal enforcement \\
\hline & R39 & Poor legal guidelines \\
\hline \multirow{16}{*}{ Environment } & $\mathrm{R} 40$ & Structure Damage \\
\hline & R41 & System Component \\
\hline & $\mathrm{R} 42$ & Water \\
\hline & $\mathrm{R} 43$ & Utility \\
\hline & $\mathrm{R} 44$ & Structure Collapse \\
\hline & $\mathrm{R} 45$ & Natural environment \\
\hline & $\mathrm{R} 46$ & Control room environment \\
\hline & R47 & Housekeeping \\
\hline & R48 & Day vs Night \\
\hline & $\mathrm{R} 49$ & Adequate Access \\
\hline & $\mathrm{R} 50$ & Air Conditioning \\
\hline & $\mathrm{R} 51$ & Fatigue \\
\hline & $\mathrm{R} 52$ & Temperature Extremes \\
\hline & $\mathrm{R} 53$ & Working alone \\
\hline & R54 & Lighting \\
\hline & R55 & Confined Spaces \\
\hline \multirow{2}{*}{ Traffic } & $\mathrm{R} 56$ & Traffic movement \\
\hline & $\mathrm{R} 57$ & Speed \\
\hline
\end{tabular}




\section{Appendix C}

Table A3. Risk Analysis and Estimation.

\begin{tabular}{|c|c|c|c|c|c|c|c|c|c|c|c|c|c|c|c|}
\hline & \multicolumn{5}{|c|}{ PORT A } & \multicolumn{5}{|c|}{ PORT B } & \multicolumn{5}{|c|}{ PORT C } \\
\hline & $\mathrm{F}$ & $\mathrm{L}$ & $S$ & $\mathrm{RR}$ & $\mathrm{RC}$ & $\mathrm{F}$ & $\mathrm{L}$ & $S$ & $\mathrm{RR}$ & $\mathrm{PC}$ & $\mathrm{F}$ & $\mathrm{L}$ & $S$ & RR & $\mathrm{RC}$ \\
\hline$R 1$ & 3.5 & 3.17 & 2.83 & 31.40 & III & 3.53 & 3.09 & 2.62 & 28.58 & II & 3.5 & 3.3 & 2.61 & 30.15 & III \\
\hline$R 2$ & 3.85 & 3.44 & 3.4 & 45.03 & III & 3.88 & 3.47 & 3.44 & 46.31 & & 3.68 & 3.61 & 3.27 & 43.44 & III \\
\hline$R 3$ & 3.33 & 3.25 & 3.42 & 37.01 & III & 3.29 & 3.41 & 3.38 & 37.92 & III & 3.34 & 3.32 & 3.27 & 36.26 & III \\
\hline$R 4$ & 3.63 & 3.58 & 2.81 & 36.52 & III & 3.53 & 3.68 & 2.65 & 34.42 & III & 3.55 & 3.7 & 2.89 & 37.96 & III \\
\hline R5 & 3.65 & 3.1 & 2.44 & 27.61 & III & 3.65 & 3.35 & 2.68 & 32.77 & III & 3.59 & 3.25 & 2.7 & 31.50 & III \\
\hline$R 6$ & 3.77 & 3.44 & 2.46 & 31.90 & III & 3.56 & 3.32 & 2.44 & 28.84 & III & 3.68 & 3.43 & 2.39 & 30.17 & III \\
\hline$R 7$ & 3.44 & 3.25 & 3.42 & 38.24 & III & 3.41 & 3.09 & 3.47 & 36.56 & III & 3.5 & 3 & 3.05 & 32.03 & III \\
\hline$R 8$ & 3.27 & 2.81 & 2.58 & 23.71 & II & 3.41 & 2.82 & 2.44 & 23.46 & II & 3.55 & 2.66 & 2.25 & 21.25 & II \\
\hline R9 & 2.9 & 3.06 & 3.06 & 27.15 & III & 2.79 & 2.94 & 3 & 24.61 & III & 3.05 & 3.07 & 2.8 & 26.22 & II \\
\hline R10 & 3.27 & 3.1 & 2.71 & 27.47 & III & 2.91 & 3.15 & 2.65 & 24.29 & II & 2.98 & 2.95 & 2.82 & 24.79 & II \\
\hline R11 & 2.9 & 2.9 & 2.42 & 20.35 & II & 2.82 & 2.62 & 2.41 & 17.81 & II & 2.82 & 2.98 & 2.41 & 20.25 & II \\
\hline R12 & 3.17 & 3.15 & 2.06 & 20.57 & II & 2.94 & 3.18 & 2 & 18.70 & II & 3.27 & 3.16 & 1.91 & 19.74 & II \\
\hline$R 13$ & 3.73 & 2.6 & 2.69 & 26.09 & II & 3.59 & 2.53 & 2.5 & 22.71 & II & 3.61 & 2.57 & 2.43 & 22.54 & II \\
\hline R14 & 3.25 & 2.21 & 2.46 & 17.67 & II & 3.06 & 2.32 & 2.53 & 17.96 & II & 3.07 & 2.2 & 2.41 & 16.28 & II \\
\hline R15 & 3.67 & 2.52 & 2.25 & 20.81 & II & 3.5 & 2.41 & 2.18 & 18.39 & III & 3.64 & 2.64 & 2. & 21.14 & II \\
\hline$R 16$ & 3.46 & 2.17 & 2.38 & 17.87 & II & 3.32 & 2.26 & 2.41 & 18.08 & II & 3.73 & 2.25 & 2.25 & 18.88 & II \\
\hline R17 & 3.38 & 2.88 & 2.85 & 27.74 & III & 3.56 & 2.59 & 2.82 & 26.00 & II & 3.64 & 3.07 & 2.84 & 31.74 & III \\
\hline$R 18$ & 3.31 & 3.15 & 3.19 & 33.26 & III & 3.18 & 3 & 2.88 & 27.48 & III & 3.5 & 3.59 & 3.0 & 38.32 & III \\
\hline R19 & 3.15 & 3.23 & 3.17 & 32.25 & III & 3 & 3.18 & 2.88 & 27.48 & III & 3.27 & 3.7 & 3.2 & 38.72 & III \\
\hline$R 20$ & 3.15 & 3.29 & 2.9 & 30.05 & III & 2.91 & 3.24 & 2.76 & 26.02 & III & 3.14 & 3.64 & 2.8 & 32.00 & III \\
\hline$R 21$ & 3.48 & 3.19 & 3.63 & 40.30 & III & 3.38 & 3.06 & 3.32 & 34.34 & III & 3.64 & 3.32 & 3.09 & 37.34 & III \\
\hline$R 22$ & 3.15 & 3.13 & 2.98 & 29.38 & III & 2.97 & 2.94 & 2.88 & 25.15 & II & 2.75 & 3.02 & 2.91 & 24.17 & II \\
\hline$R 23$ & 3.02 & 2.98 & 2.65 & 23.85 & II & 3 & 2.79 & 2.62 & 21.93 & II & 2.95 & 2.84 & 2.93 & 24.55 & II \\
\hline$R 24$ & 3.13 & 2.85 & 2.67 & 23.82 & II & 2.88 & 2.82 & 2.65 & 21.52 & II & 2.89 & 2.84 & 2.82 & 23.15 & II \\
\hline$R 25$ & 3.21 & 3.08 & 2.38 & 23.53 & II & 3 & 3 & 2.44 & 21.96 & II & 3.18 & 2.98 & 2.61 & 24.73 & II \\
\hline$R 26$ & 3.1 & 3.02 & 2.92 & 27.34 & III & 2.82 & 2.82 & 2.76 & 21.95 & III & 3.09 & 2.98 & 3.16 & 29.10 & III \\
\hline$R 27$ & 3.15 & 2.92 & 2.69 & 24.74 & II & 2.76 & 2.82 & 2.71 & 21.09 & II & 3.05 & 2.7 & 2.8 & 23.06 & II \\
\hline$R 28$ & 2.92 & 2.81 & 2.9 & 23.80 & II & 2.88 & 2.71 & 2.82 & 22.01 & II & 2.98 & 2.7 & 2.8 & 22.53 & II \\
\hline$R 29$ & 3.19 & 3.19 & 3.06 & 31.14 & III & 3 & 3.06 & 2.88 & 26.44 & II & 3.18 & 3.02 & 2.93 & 28.14 & III \\
\hline$R 30$ & 3.21 & 3.02 & 3.04 & 29.47 & III & 3.06 & 2.76 & 3.24 & 27.36 & II & 2.95 & 2.86 & 3.14 & 26.49 & II \\
\hline R31 & 3.6 & 3.13 & 3.04 & 34.25 & III & 3.38 & 2.97 & 2.94 & 29.51 & II & 3.36 & 3.2 & 2.77 & 29.78 & III \\
\hline R32 & 3.21 & 2.75 & 3.04 & 26.84 & II & 2.91 & 2.56 & 3.06 & 22.80 & II & 2.7 & 2.86 & 3.16 & 24.40 & II \\
\hline R33 & 3.38 & 3.25 & 3.17 & 34.82 & III & 3.15 & 3.12 & 3.06 & 30.07 & III & 2.82 & 3.32 & 3.25 & 30.43 & III \\
\hline R34 & 3.17 & 2.6 & 3.13 & 25.80 & II & 2.88 & 2.47 & 2.94 & 20.91 & III & 3.34 & 2.89 & 2.82 & 27.22 & III \\
\hline R35 & 3.27 & 3.4 & 3.38 & 37.58 & III & 3.18 & 3.09 & 3.09 & 30.36 & III & 3.05 & 2.95 & 3.25 & 29.24 & III \\
\hline R36 & 3.15 & 2.73 & 2.98 & 25.63 & II & 3.06 & 2.76 & 2.82 & 23.82 & II & 3.11 & 2.8 & 2.95 & 25.69 & II \\
\hline R37 & 3.21 & 3.23 & 2.67 & 27.68 & III & 2.88 & 2.97 & 2.65 & 22.67 & II & 3.18 & 2.89 & 2.93 & 26.93 & II \\
\hline
\end{tabular}


Table A4. Risk Analysis and Estimation.

\begin{tabular}{|c|c|c|c|c|c|c|c|c|c|c|c|c|c|c|c|}
\hline & \multicolumn{5}{|c|}{ PORT A } & \multicolumn{5}{|c|}{ PORT B } & \multicolumn{5}{|c|}{ PORT C } \\
\hline & F & $\mathrm{L}$ & $S$ & RR & $\mathrm{RC}$ & F & $\mathrm{L}$ & S & RR & $\mathrm{RC}$ & $\mathrm{F}$ & $\mathrm{L}$ & S & RR & $\mathrm{RC}$ \\
\hline R38 & 3.13 & 2.79 & 3.15 & 27.51 & III & 2.94 & 2.76 & 2.76 & 22.40 & II & 3.05 & 2.66 & 2.89 & 23.45 & II \\
\hline R39 & 3.13 & 2.9 & 3.08 & 27.96 & III & 2.94 & 2.71 & 3 & 23.90 & II & 3.16 & 2.66 & 2.93 & 24.63 & II \\
\hline$R 40$ & 3.35 & 3.25 & 3.04 & 33.10 & III & 3.32 & 3.18 & 2.88 & 30.41 & III & 3.25 & 3.41 & 3.07 & 34.02 & III \\
\hline$R 41$ & 3.31 & 3.04 & 2.98 & 29.99 & III & 3.32 & 2.94 & 2.94 & 28.70 & III & 3.23 & 2.77 & 2.91 & 26.04 & II \\
\hline R42 & 3 & 2.85 & 2.27 & 19.41 & II & 2.76 & 2.91 & 2.18 & 17.51 & II & 2.82 & 2.8 & 2.34 & 18.48 & II \\
\hline$R 43$ & 3.08 & 2.96 & 3.02 & 27.53 & III & 2.82 & 2.82 & 2.94 & 23.38 & II & 2.89 & 2.84 & 3.02 & 24.79 & II \\
\hline$R 44$ & 3.1 & 3.04 & 2.96 & 27.90 & III & 3 & 2.94 & 2.88 & 25.40 & II & 2.86 & 2.91 & 2.98 & 24.80 & II \\
\hline$R 45$ & 2.81 & 3.21 & 3.42 & 30.85 & III & 3.09 & 2.47 & 3.41 & 26.03 & III & 2.91 & 3.55 & 3.34 & 34.50 & III \\
\hline$R 46$ & 2.98 & 2.98 & 2.46 & 21.85 & II & 2.82 & 2.88 & 2.38 & 19.33 & II & 2.77 & 2.75 & 2.66 & 20.26 & II \\
\hline R47 & 3.1 & 2.75 & 2.54 & 21.65 & II & 3.12 & 2.76 & 2.62 & 22.56 & II & 3.05 & 2.52 & 2.91 & 22.37 & II \\
\hline$R 48$ & 3.15 & 2.77 & 2.13 & 18.59 & II & 3.24 & 2.59 & 2.24 & 18.80 & III & 3.18 & 2.39 & 2.14 & 16.26 & II \\
\hline$R 49$ & 3.08 & 3.21 & 2.79 & 27.58 & III & 3.12 & 3 & 2.71 & 25.37 & II & 3.14 & 3 & 2.8 & 26.38 & II \\
\hline R50 & 3.21 & 2.92 & 2.73 & 25.59 & II & 3.47 & 2.82 & 2.56 & 25.05 & II & 3.32 & 2.89 & 2.45 & 23.51 & II \\
\hline R51 & 3.96 & 3.23 & 3.19 & 40.80 & III & 3.79 & 3.44 & 3.12 & 40.68 & III & 3.89 & 3.68 & 3.16 & 45.24 & III \\
\hline R52 & 3.02 & 2.71 & 2.46 & 20.13 & II & 3 & 2.62 & 2.41 & 18.94 & II & 3.07 & 2.93 & 2.3 & 20.69 & II \\
\hline R53 & 3.65 & 3.04 & 2.83 & 31.40 & III & 3.32 & 3 & 2.76 & 27.49 & III & 3.25 & 2.86 & 2.77 & 25.75 & II \\
\hline R54 & 3.13 & 2.88 & 2.46 & 22.18 & II & 2.94 & 2.76 & 2.44 & 19.80 & II & 2.95 & 2.8 & 2.48 & 20.48 & II \\
\hline R55 & 3.25 & 2.4 & 2.96 & 23.09 & II & 3.18 & 2.44 & 2.85 & 22.11 & II & 3.23 & 2.43 & 2.98 & 23.39 & II \\
\hline$R 56$ & 3.15 & 2.88 & 2.92 & 26.49 & II & 2.94 & 2.88 & 2.88 & 24.39 & II & 2.95 & 2.86 & 2.66 & 22.44 & II \\
\hline R57 & 3.73 & 3.48 & 3.17 & 41.15 & III & 3.85 & 3.47 & 3.06 & 40.88 & III & 3.59 & 3.59 & 3.02 & 38.92 & III \\
\hline
\end{tabular}

\section{References}

1. Lee, P.T.W.; Kwon, O.K.; Ruan, X. Sustainability Challenges in Maritime Transport and Logistics Industry and Its Way Ahead. Sustainability 2019, 11, 1331. [CrossRef]

2. Kang, D.; Kim, S. Conceptual Model Development of Sustainability Practices: The Case of Port Operations for Collaboration and Governance. Sustainability 2017, 9, 2333. [CrossRef]

3. Sislian, L.; Jaegler, A.; Cariou, P. A Literature Review on Port Sustainability and Ocean's Carrier Network Problem. Res. Transp. Bus. Manag. 2016, 19, 19-26. [CrossRef]

4. Zhao, B. Facts and lessons related to the explosion accident in Tianjin Port, China. Nat. Hazards 2016, 84, 707-713. [CrossRef]

5. Fabiano, B.; Currò, F.; Reverberi, A.P.; Pastorino, R. Port safety and the container. Saf. Sci. 2010, $48,9808$.

6. Marine Industrial Accident Statistics. Available online: https://www.mardep.gov.hk/en/publication/mias.html (accessed on 15 November 2019).

7. Port Industry Accident Statistics. published on 10 July 2018. Available online: https://www. portskillsandsafety.co.uk/resources (accessed on 15 November 2019).

8. Ng, C.A.; Berg, M.B.; Jude, D.J.; Janssen, J.; Charlebois, P.M.; Amaral, L.A.N.; Ray, K.A. Chemical amplification in an invaded food web: Seasonality and ontogeny in a high-biomass, low-diversity ecosystem. Environ. Toxicol. Chem. 2008, 27, 2186-2195. [CrossRef] [PubMed]

9. Shang, K.C.; Tseng, W.J. A Risk Analysis of Stevedoring Operations in Seaport Container Terminals. J. Mar. Sci. Technol. 2010, 18, 201-210.

10. Tseng, P.H.; Pilcher, N. Maintaining and researching port safety: A case study of the port of Kaohsiung. Eur. Transp. Res. Rev. 2017, 9, 34. [CrossRef] 
11. Pallis, P.L. Port Risk Management in Container Terminals. Transp. Res. Procedia 2017, 25, 4411-4421. [CrossRef]

12. Yang, Y.L.; Ding, J.F.; Chiu, C.; Shyu, W.S.; Tseng, W.J.; Chou, M.T. Core risk factors influencing safe handling operations for container terminals at Kaohsiung port. J. Eng. Marit. Environ. 2016, 230, 444-453. [CrossRef]

13. Alyami, H.; Lee, P.T.-W.; Yang, Z.; Riahi, R.; Bonsall, S.; Wang, J. An advanced risk analysis approach for container port safety evaluation. Marit. Policy Manag. 2014, 41, 634-650. [CrossRef]

14. Alyami, H.; Yang, Z.; Riahi, R.; Bonsall, S.; Wang, J. Advanced uncertainty modelling for container port risk analysis. Accid. Anal. 2016, 123, 411-421. [CrossRef] [PubMed]

15. American Bureau of Shipping. Risk Assessment Applications for the Marine and Offshore Oil and Gas Industries. 2000. Available online: https:/ww2.eagle.org/content/dam/eagle/rules-and-guides/current/other/ 97_riskassessapplmarineandoffshoreoandg/pub97_riskassesment.pdf (accessed on 12 March 2017).

16. International Convention for the Safety of Life at Sea (SOLAS), 1974. Adoption: 1 November 1974; Entry into Force: 25 May 1980; International Maritime Organization (IMO): London, UK, 1974.

17. Malaysa Marine Department. Merchant Shipping (Amendment and Extension) Act 2007; Percetakkan Nasional Malaysia Bhd: Kuala Lumpur, Malaysia, 2007.

18. International Maritime Organization. Available online: http://www.imo.org/en/About/Pages/Default.aspx (accessed on 11 November 2019).

19. Jabatan Laut Malaysia. Malaysia Port by Law, Pelabuhan Klang, Malaysia. 1963. Available online: http://www.pka.gov.my/index.php/en/download/category/87-by-laws (accessed on 11 November 2019).

20. Department of Safety of Health Malaysia. Occupational Safety and Health Act (Act 514), Ministry of Human Resources, Federal Government Administrative Centre, Putrajaya. 1994. Available online: http://www.dosh.gov.my/index.php/list-of-documents/acts/23-02-occupational-safety-and-healthact-1994-act-514/file (accessed on 11 November 2019).

21. Department of Safety of Health Malaysia. Factories and Machineries Act (Act 139), Ministry of Human Resources, Federal Government Administrative Centre, Putrajaya. 1967. Available online: http://www.dosh.gov.my/index.php/list-of-documents/acts/26-03-factories-and-machinery-act-1967revised-1974-acts-139/file (accessed on 11 November 2019).

22. Department of Safety of Health Malaysia. Guidelines for Hazard Identification, Risk Assessment and Risk Control (HIRARC), Ministry of Human Resources, Federal Government Administrative Centre, Putrajaya. 2008. Available online: http://www.dosh.gov.my/index.php/competent-person-form/occupational-health/ regulation/guidelines/hirarc-2/1846-01-guidelines-for-hazard-identification-risk-assessment-and-riskcontrol-hirarc-2008? path=guidelines/hirarc-2 (accessed on 11 November 2019).

23. International Maritime Organization. Formal Safety Assessment. 2002. Available online: http://www.imo. org/en/OurWork/Safety/SafetyTopics/Pages/FormalSafetyAssessment.aspx (accessed on 11 November 2018).

24. Vidmar, P.; Perkovic, M. Methodological approach for safety assessment of cruise ship in port. Saf. Sci. 2019, 80, 189-200. [CrossRef]

25. Bouda, A.; Bachari, N.E.I.; Bahmed, L.; Boubenia, R. Design of a risk assessment methodology for the introduction of invasive species from ship ballast waters: The case of Arzew port. Manag. Environ. Qual. 2016, 27, 1-5. [CrossRef]

26. Wang, J.; Wang, P.; Zoua, X.W.; Li, P.P. Critical factors and paths influencing construction workers' safety risk tolerances. Accid. Anal. Prev. 2016, 93, 267-279. [CrossRef] [PubMed]

27. Haapasaari, P.; Helle, I.; Lehikoinen, A.; Lappalainen, J.; Kuikka, S. A proactive approach for maritime safety policy making for the Gulf of Finland: Seeking best practices. Mar. Policy 2015, 60, 107-118. [CrossRef]

28. Dong, Y.; Frangopol, D.M. Probabilistic ship collision risk and sustainability assessment considering risk attitudes. Struct. Saf. 2015, 53, 75-84. [CrossRef]

29. Kadir, Z.A. Risk Management Framework of Handling and Storage of Cargo at Ports in Malaysia. Master's Thesis, Universiti Teknologi Malaysia, Skudai, Johor Bahru, Malaysia, 2019.

30. Mokhtari, K.; Ren, J.; Roberts, C.; Wang, J. Decision support framework for risk management on seaports and terminals using fuzzy set theory and evidential reasoning approach. Expert Syst. Appl. 2012, 39, 5087-5103. [CrossRef]

31. United Nation Sustainability Goal Development Number Nine. Industry Innovation and Infrastructure. Available online: https:/academicimpact.un.org/content/industry-innovation-and-infrastructure (accessed on 11 November 2019). 
32. Sunaryo, J.; Hamka, M. Safety Risks Assessment on Container Terminal Using Hazard Identification and Risk Assessment and Fault Tree Analysis Methods. Procedia Eng. 2017, 194, 307-314. [CrossRef]

33. Azmi, M. Ergonomics of Quay Crane Workstation; (Thesis); Universiti Teknologi Malaysia (UTM): Skudai, Johor Bahru, Malaysia, 2017. 